\title{
Humorous Teaching in College English Class
}

\author{
Lin KANG \\ Basic Courses Teaching Department, The Chinese People's Armed Police Force Academy, \\ LangFang, Hebei, China \\ 179888852@qq.com
}

Keywords: Humor, College English teaching.

\begin{abstract}
This essay is talking about the humorous teaching in college English class. "Humor" is an effective way to inspire students' interests in class. College English teachers ought to realize the importance of using humorous teaching method, and learn how to use it correctly and effectively to make it become the powerful tool for English teaching and the perfectly attached teaching materials for students.
\end{abstract}

\section{Introduction}

Nowadays the English teaching performs a leading function in learning English, gaining the systematic English knowledge, and grasping and applying all kinds of English knowledge correctly. In view of the significance of the class teaching in the teaching procedures, the effective application of humor in college English class holds an enormous importance. It is a kind of ability of the English teacher which can inspire students' interests during the English learning. The natural instinct of human is keen on playing. If given the choices, most students would prefer playing to studying and would praise highly a motto "All work and no play makes Jack a dull boy". Therefore, English teachers should combine the amusement and study properly to make humorous teaching be a bridge from play to study. [1]

\section{Advantages of Humorous Teaching in College English Class}

Using the humorous teaching method effectively in college English class can get many gains.

\section{Release Tension}

Humor can cause laughter, and laughter is proved to be good for relaxing people's spirits in physiological research. And to gain the knowledge needs a kind of tension, however, the tensive study about the continuous fifty minutes can lead the students to a great spiritual pressure. If English teachers can offer some humorous materials for students frequently during giving lessons to make them laugh, their intensive emotions can be mitigated and their study efficiency can be improved.

\section{Promote Bounding}

Humor is helpful to promote the relationship among the people and can bring us the comprehension, friendship and communication with each other. This aspect is not only fit for the life of nowadays, but also for the English teaching. If both the teachers and the students could enjoy the humor and laugh together, in fact, they have understood each other deeply.

\section{Arouse Enjoyment}

Students need interests when learning English. If English teachers could use the humor to arouse students to laugh when giving lessons, they would make the procedures of learning English less of a chore and more of an enjoyment. If some complex English sentence patterns or phrases can compose funny and interesting concepts, knowledge will be made a very deep impression on students and can be digested and absorbed unconsciously. 


\section{Forms of Humor Used in College English Class}

Since the humor can bring so many advantages for the English teaching, as a college English teacher, it's the duty to use it abundantly. By looking for some materials and studying them carefully, some types of humor is quite good.

\section{English Word Puzzles}

The English word puzzles appear a kind of abstract structure and offer some information for students, and the students can distinguish the linguistic information. This kind of game combines the interests and the words, which is helpful to make the students get rid of the monotonousness and remember the words with enjoyment.

As for the range of English word puzzles, the teachers can perform systemically according to the semesters or the academic years. And the knowledge concerned had better be from easy to difficult. For example, at first, the teachers can ask the students to fill the simple pictures, they will know the pleasure of victory and the satisfaction of success. Then the teachers can introduce some difficult English word puzzles in a kind of complex structure. For instance, this can be concerned about the time, country, food, animals, and transportations and so on. By this means, students can also remember the difficult words. Because they experience a period of recognizing and analysing words, in the end, they can learn these words by heart very well.

\section{English Humorous Stories}

There are so many English humorous stories, which are concerned about love, family, friendship, and success and so on in English. The teachers can choose some humorous stories to read for students, then ask them some questions about this story or make an exercise to let the students fill the blanks according to the content of this story. It is good for them to practice the ability of speaking, listening and reading. For example:

"When Mark Twain edited a newspaper in Missouri, one of his subscribers wrote him that he had found a spider in his paper and wished to know whether it meant good luck of bad. Twain replied: "Finding a spider in tour paper is neither good luck nor bad. The spider was merely looking over our paper to see which merchant was not advertising, so that he could go to that store, spin his web across the door and head a life of undisturbed peace ever afterwards!'[2]

After finishing telling this story, the teachers can put forward some questions as following:

"What had one subscriber found in his papers?"

"What did the subscriber ask Mark Twain?"

"How did Mark Twain reply?"

If most of the students feel it difficult to get the answers, teachers can read the story once again and explain some difficult words and phrases, such as "spider", "look over a paper" and "spin his web" and so on. Then the students could understand the story better and get the answers easily and correctly. After that, the teachers can write this short story on the blackboard, which makes the students grasp the whole meaning of the story directly and improve their abilities of comprehension and using English knowledge.

In all, English humorous stories need to be chosen to take account of the learners' likely listening and reading needs and interests. Teachers would have to learn to ensure that the atmosphere in their classrooms was one which would encourage even the most shy students to try to use their linguistic knowledge to expresse interpret meanings.

\section{English Jokes}

English jokes are used in the language teaching, which can arouse the students' interests and help them get rid of embarrassment easily and communicate with each other successfully, at the same time, also can let them know the life style and western cultures. For example:

One day, the famous scientist Albert Einstein came across an old friend of his in a street in New York. The friend said that his overcoat was too worn-out and that he should have a new one. "It 
doesn't matter," answered Albert Einstein, "No one knows me here in New York." Several years later, they met in New York again, Einstein had become a world-famous physicist by then, but he still wore the same old overcoat. Once more his friend tried to persuade him to buy a new one.

"There's no need now," said Einstein, "Everybody here knows me." [3]

For many years, Einstein' overcoat has not been renewed. No one knew him before he became famous in the world, however, he thought there was no need to change his overcoat after he had become a world-famous person because everyone has known him. This is a joke, which reflects Einstein's intelligence and his attitude towards life. And at the same time, the students have learned about some English sentence patterns, such as "It doesn't matter." "There is no need." And so on.

\section{Act Out Short Play, Create Situation}

English teachers should realize the importance of the situation where students stay. Therefore, it is a way of making the students act the play in class. Students can be involved in the situation with the content of play, they would be interested in the things that are going to happen and have motive to act and attend the class. In the end, the lesson will become a vivid and vigorous one with this method. The learners benefit from the whole procedure of language teaching. English teachers ought to adopt many ways to create the relaxed situation, so the results on study will be more effective.

\section{The Aspects Paid Attention to about Humor during Class}

Teachers cannot use the same tool for every purpose. We must consider the appropriateness of a given tool and its effectiveness in context to achieve a particular goal. [4] Here are the aspects college English teachers should pay attention to when they use the humor in class.

Firstly, the humorous teaching method should serve for the aim of English teaching. The humor is the means of improving the affectation of teaching, so the humor must link with the content of teaching, and combine with the theme of lessons given. We could not speak carelessly and make the humor simply, and the unprincipled humor should be prohibited from getting into the step.

Secondly, grasp the chance properly. When the disciplines of class is lax, the students could not focus on the lessons; when the students are tired; when the mood of the students are nervous; when the teacher and the students are in embarrassment, if the teacher use the humor effectively, he can succeed in dealing with the problem and the classroom could become vivid and vigorous.

Thirdly, pay attention to the condition used. The humor should be used in a kind of definite conditions. Otherwise, it is easy to be misunderstood by the students and would not read the purpose. And these conditions include that the relationship between the teachers and the students is close or not. Whether the time and the situation is suitable or not? Whether the language context is fitting or not? For example, if the teacher wants to remind a student who took a nap by using the humor during the class, this teacher should pay attention to the relationship with him and the character of this student, if their relationship is common and this student is shy, maybe he is hurt. In all, the teacher should take note of the target.[5]

Besides, teachers had better notice the content of humor used in class, some humors may bruise feelings or loss of face, hence, the teachers should try to be careful when they use the humor and stand in the shoes of students, some humors may directly or indirectly concern pornography and racial discrimination, the teacher should remind himself not to let this kind of thing happen. Only the right contents of humor can lead the students correctly and serve for education positively.

\section{Conclusion}

Teachers and students' roles in the classroom presuppose a good classroom atmosphere. The teachers ought to know their students' needs and interests and be imaginative enough to use their knowledge, for at least part of the time to use humor properly, the relationship between the teacher and the students can be more better, the atmosphere of class can be moved vividly, so the students can digest 
and accept the lessons more easily, and the teacher can improve the level of teaching and the ability of professional work.

\section{References}

[1] Keith Johnson, An Introduction to Foreign Language Learning and Teaching, Foreign Language Teaching and Research Press, Beijing, 2002.

[2] Bin Bin, Selection of New Foreign Humor Stories, Mongolia Culture Press, Hailar, 2003, pp.77.

[3] Bin Bin, Selection of New Foreign Humor Stories, Mongolia Culture Press, Hailar, 2003, pp.81.

[4] Ronald A. Berk, Homor as an Instructional Defibrillator: Evidence-based Techniques in Teaching and Assessment, Stylus Publishing, PA, 2002.

[5] Wedell. M, Language Teaching \& Learning From Theory to Practice, Higher Education Press, Beijing, 1995. 